\title{
Assessing the Impact of European Funding on Local Development
}

\author{
Florina Bran \\ Mihaela Minciu \\ Razvan Catalin Dobrea \\ Carmen Valentina Radulescu \\ Bucharest University of Economic Studies, Romania
}

\begin{abstract}
This paper aims to analyze the impact of local development projects funded by European funds on disadvantaged local comunities in rural areas. Starting from the many studies and research from this area, the paper „Assessing the impact of European funds on local development" aims to present subjects of general interest, such as local development concepts, the project with European funding. At the same time, the present study seeks to identify the positive effects of the local development process on the communities in which it is being implemented. In general, the local development process aims to implement projects that improve the quality of services community members have access to, foster economic activity in the area and reduce disparities between rural and urban areas. In rural areas, there are many people who have abandoned the education system early on, who are unaware of their rights, with health problems, inactive or unemployed, being discriminated and lacking of any support. Therefore, local development calls for the unification of all stakeholders in a community, both local actors and beneficiaries, in order to attract funds and implement projects to adress disadvantageous phenomena and identify possible opportunities that may have a positive impact on localities. Also, through local development projects, the present situation of a community can be improved by making the resources more efficient and by inteligently organizing and coordinating the services provided to the locals.
\end{abstract}

Keywords: project, local development, European funds

\section{Introduction}

The local development process represents the main way for a community to act to reduce the poverty rate present in that area in order to support families and disadvantaged groups. Through this process, localities can more intelligently exploit natural and human capital, favoring the emergence of investors in the area, thus stimulating economic activity, giving community members the chance to integrate more easily into the labor market, and provide the necessary income for everyday life.

This paper will be divided into four chapters in which will be exposed various aspects of European-funded local development projects: their characteristics, the main actors, the modalities of analysis and control, the subsequent impact of these activities on communities in which is being implemented.

In order to identify the effects of these projects, it was analyzed a local development project funded through the Capital Uman Operational Program, which is being implemented in Giurgiu County, in the South-Muntenia region.

So, if in the first part of the paper are presented different theoretical aspects referring to the local development process and projects, the theoretical notions will be used in the next part to analyze the results obtained after evaluating the effects of the project, and in the last part will be presented conclusions and recommendations, in order to increase the efficiency of these projects. All analyzes and proposals made to study the impact of projects on the community represent situations that can be used as landmarks for the development of such initiatives in Romania.

\section{Literature review regarding local development}

Every process of local development begins from an analysis of the present state in order to identify the main aspects (areas) that need to be improved, to determine the means of action and 
the main risks or difficulties that can appear. Following the community-based analysis, it can be decided whether there are certain opportunities that can be exploited, in order to increase the standard of living and the level of economic development.

A very important aspect in the local development process is represented by equity, respectivelly all attempts by local communities to improve the quality of life and support vulnerable categories, so that these people also have equal opportunities to access certain medical and educational services and for insertation into the labour market [9].

Local development is achieved through the implementation of a project, respectively by setting a set of objectives and by planning the activities and resources needed. Local development projects with European-funded are the easiest and most important way for disadvantaged rural communities to improve their living standards.

Local development activities which have the purpose changing, favoring certain actions capable of generating positive effects are based on a strategy, because they also have to look at all the geographical, historical, natural elements before launching any project. Depending on the level of involvement of local authorities for the implementation of local development projects, various partnerships can be created through which community members can more easily access certain public services or promote their cultural traditions and values.

In most cases the objectives of a community can be realized through local development projects and partnering with different organizations and associations. The benefits of partnerships include: improving or maintaining the current state of the products and services in terms of quality, cost reduction, risk sharing, obtaining different economic facilities.

It is considered that a local development project will have a positive impact on the community if the following conditions are accomplishing: the project will be delivered

in time, within the initial projected timeframe, the results initially set will be reached from a qualitatively and quantitatively point of view, and the resources initially planned (material, financial, human) will be sufficient to achieve all the objectives [1].

Through the partnerships established, in order to implement a local development project, can be introduced elements of innovation that facilitate the organization, coordination and operation of services. Also, in many cases, through project partnerships can be purchased new technologies that reduce production costs and improve the quality of services provided to community citizens.

\section{Local development projects with European-funded}

As a result of Romania's integration into the European Union, poor rural communities have had the opportunity through projects with European funded to progress, to improve their economic situation, to exploit their natural resources and capitalize on their potential tourism.

Local development projects, depending on the program and the priority axis accessed, may aim to reduce the phenomenon of social exclusion, poverty, the number of disadvantaged groups, discrimination, and to promote tourist areas, to improve infrastructure, to capitalize agricultural production and to facilitate people's access to services education, health and the acquisition of new qualifications in order to integrate into the labor market.

Constantinescu, Anghel, Ungureanu and Pridie (2001) consider that "a project is a sequence of interrelated actions that take place in a defined period of time, actions aimed at achieving unique objectives and at the same time precise" [2].

A project that does not produce positive, superior effects and does not accomplish the performance criteria is considered to be a failure because it does not contribute to alleviating the difficult situation of a locality or exploits an opportunity.

Any project "starts with identifying the need that will be satisfied by the project, depending on the expectations of the stakeholders and the internal constraints of the promoter organization" [4].

After the need analysis has been established, the objectives to be achieved by the implementation of the project are determined, the main activities necessary for achieving the project goal are planned, the target group is determined, each activity is analyzed and planned, both temporarily 
and from the point of view of resource requirements (material, human, financial), then are defined the results to be achieved at the completion of each activity.

In a project may be recorded various deviations, particularly in the context of budgeting which affect the performance of activities or the timing of project-specific actions.

Gareis (2010) considers that any deviation that occurred during the implementation of the project is a great opportunity for the project, because the information and implicitly all the experience gained from its overcoming will be available for possible future situations [5].

In general, to overcome all the malfunctions and to effectively solve the problems that arise, is required a good coordination of project team members and, if necessary, the contracting of external experts.

The main factors that ensure the success of a project are [6]: a clear and rigorous definition of the project, the planning and availability of resources, the skills of the project team and the communication process established between them, the motivation of the manager and the project team, the way of handling and solving conflicts between project stakeholders.

Performance monitoring is a crucial activity because it represents the reason for implementing a local development project [7]. Therefore, if the project is not performing it will not be able to achieve its goals and will not produce positive future effects.

From the socio-economic point of view, to estimate the total benefits, reported to the total costs in the community where a local development project has been implemented, is used an analytical tool: cost-benefit analysis (CBA).

The role of the cost-benefit analysis is to "identify and quantify (or give monetary value) all the possible impacts of the actions characteristic of the analyzed project in order to determine the appropriate costs and benefits" [3].

Therefore, is carried out an analysis to assess the costs and benefits resulting from two scenarios: the scenario that will result from the project implementation and the current state without a project.

After the analysis, it can clearly see the opportunities that will be created for the members of the community and the usefulness of the investment that will be financed. Also, with the costbenefit analysis, it can be decided whether a local development project deserves assistance and grants.

The cost-benefit analysis has the role of estimating and summing up the monetary equivalent of all future benefits and costs that are characteristic of public investment projects to determine whether any actions are in the interest of citizens [11].

Based on this analysis, it can be decided whether the project contributes to the economic development of the community or region in which it is being implemented and whether it deserves to be co-financed from the European Union budget. Through the cost-benefit analysis, respectively the economic and financial assessment of the project, including the risk analysis, it can be appreciate if the project influences the progress of a country, the effects generated for the members of the region or the community in which it is implemented, reported at all the necessary efforts, and the contribution to the objectives of the European Union [10].

In order for the benefits generated by the implementation of the local development project to be higher than the costs, particular attention should be granted to all these elements: from the time of writing the project so that there's no confusion and the project team members know from the moment of employment the main aspects of the project that must be taken into consideration as well as the benefits or rewards that they will receive if the activities are fulfilling their results.

Based on the cost-benefit analysis, it can be concluded whether the local development project has produced positive effects on the region where it has been implemented and how it contribute to increase in the quality of life. 


\section{The analysis of the project implemented in Greaca commune}

In order to determine the impact of projects with European-funded on the development of local communities, research has been carried out within the project that is being implemented in the South-Muntenia region, respectively in Greaca commune.

Greaca commune is an old border town with a rich and interesting history, especially due to the immediate proximity of the former pond (the famous pond Greaca), about $9 \mathrm{~km}$ from the Danube, in the south-eastern part of the county Giurgiu.

The first attestation of the locality dates back to 1532, when Vlad Voevod (the son-in-law of Petru Rares) visited these places [8].

In order to support the disadvantaged families and the vulnerable groups, as well as to improve the living standards of the inhabitants, the representatives of the Greaca commune in partnership with the Gymnasium School Nr. 1 Greaca and two other members (St. Stelian Association (solicitant) and Eco Rural Consulting SRL-D) have proposed to implement a project covering 5 areas: education, socio-medical services, entrepreneurship, occupation and habitation.

The project has been successfully approved and is currently being implemented. The project is funded through the POCU Program - the Human Capital Operational Program, Priority Axis 4. The Specific Objective 4.2 aims to reduce the number of marginalized communities or in precarious situations, the poverty and the risk of social exclusion through the implementation of integrated measures. So through this project will be offered educational services for 224 people (40 preschoolers, 160 pupils and 24 adults), employment services for 336 people (276 inhabitants will receive training and professional guidance services, 60 people will follow entrepreneurship courses and 30 people will benefit from apprenticeships at employers within the commune), socio-medical services for all 560 people, rehabilitation services for 70 households and legal assistance for 150 families, and will be awarded 22 grants for the people who want to start new businesses.

In the support given to the target group special attention was granted to disadvantaged women (who lacked a professional qualification and low educational level), to people who belong to the Roma minorities and to persons with chronic diseases and disabilities. Because the project is underway, surveys have been carried out to the education component, and its characteristic activities are advanced compared to the others.

To determine whether the influence of extracurricular activities on children's results is significant, it has been realized a statistical interpretation of the data, using the Fisher Test of dispersal analysis. The statistical population was made up of all pupils who participated in extracurricular activities and competitions. The sample was represented by the 81 pupils who had to choose the number of points (per total) with which the school performance was improved compared to the previous ones (the children could choose between 0 and 5 points).

Tabel 3.1 Educational activities

\begin{tabular}{|c|c|c|c|c|}
\hline \multirow{2}{*}{ Educational activities } & \multicolumn{4}{|c|}{ Growth points of school results (notes) } \\
\cline { 2 - 5 } & $0-2(j=1)$ & $2-4(j=2)$ & $4-6(j=3)$ & Total \\
\hline a IV - a $(\mathrm{i}=1)$ & 12 & 2 & 2 & $\mathbf{1 6}$ \\
\hline $\mathrm{a}$ V $-\mathrm{a}(\mathrm{i}=2)$ & 10 & 2 & 3 & $\mathbf{1 5}$ \\
\hline $\mathrm{a}$ VI $-\mathrm{a}(\mathrm{i}=3)$ & 8 & 5 & 2 & $\mathbf{1 5}$ \\
\hline $\mathrm{a}$ VII $-\mathrm{a}(\mathrm{i}=4)$ & 12 & 2 & 3 & $\mathbf{1 7}$ \\
\hline $\mathrm{a}$ VIII - a $(\mathrm{i}=5)$ & 2 & 9 & $\mathbf{1 7}$ & $\mathbf{8 1}$ \\
\hline Total & $\mathbf{4 4}$ & $\mathbf{2 0}$ & & \\
\hline
\end{tabular}

Source: own creation

$\mathrm{x}$ - independent variable (educational activities)

$\mathrm{y}$ - dependent variable (Growth points of school results - notes)

To calculate how school activities influenced the children's results, will be calculated the averages and dispersions for each group (these will be calculated as weighted arithmetic mean). 
1. $i=1$ (fourth grade)

Tabel 3.2 Educational activities carried out at the fourth grade

\begin{tabular}{|c|c|c|c|c|}
\hline $\begin{array}{c}\text { Growth points of } \\
\text { school results (notes) }\end{array}$ & $\begin{array}{c}\text { Number } \\
\text { of answers } \\
\left(\mathrm{n}_{1 \mathrm{i}}\right)\end{array}$ & $\begin{array}{c}\text { Interval } \\
\text { center }\left(\mathrm{y}_{1 \mathrm{j}}\right)\end{array}$ & $\mathrm{y}_{1 \mathrm{j}}{ }^{*} \mathrm{n}_{1 \mathrm{j}}$ & $\left(\mathrm{y}_{1 \mathrm{j}}-\mathrm{y}_{1 \text { middle }}\right){ }^{2}{ }^{*} \mathrm{n}_{1 \mathrm{j}}$ \\
\hline $0-2$ & 12 & $(0+2) / 2=1$ & $1 * 12=12$ & $(1-1,75)^{2} * 12=6,75$ \\
\hline $2-4$ & 2 & $(2+4) / 2=3$ & $3 * 2=6$ & $(3-1,75)^{2} * 2=3,13$ \\
\hline $4-6$ & 2 & $(4+6) / 2=5$ & $5 * 2=10$ & $(5-1,75)^{2} * 2=21,13$ \\
\hline Total & $\mathbf{1 6}$ & $\mathbf{-}$ & $\mathbf{2 8}$ & $\mathbf{3 1 , 0 1}$ \\
\hline
\end{tabular}

Source: own creation

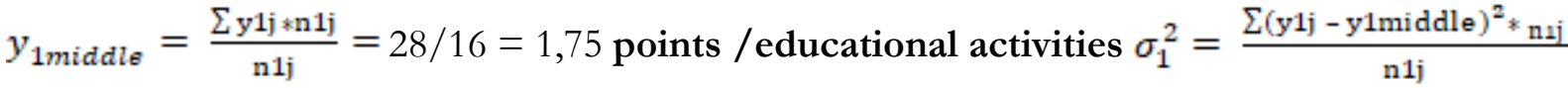
$=31,01 / 16=\mathbf{1 , 9 4}$

1. $i=2$ (fifth grade)

Tabel 3.3 Educational activities carried out at the fifth grade

\begin{tabular}{|c|c|c|c|c|}
\hline $\begin{array}{c}\text { Growth points of } \\
\text { school results (notes) }\end{array}$ & $\begin{array}{c}\text { Number } \\
\text { of answers } \\
\left(\mathrm{n}_{2 \mathrm{j}}\right.\end{array}$ & $\begin{array}{c}\text { Interval } \\
\text { center }\left(\mathrm{y}_{2 \mathrm{j}}\right)\end{array}$ & $\mathrm{y}_{2 \mathrm{j}} *_{\mathrm{n}_{2 \mathrm{j}}}$ & $\left(\mathrm{y}_{2 \mathrm{j}}-\mathrm{y}_{2 \mathrm{j} \text { middle }}\right)^{2}{ }_{\mathrm{n}_{2 \mathrm{j}}}$ \\
\hline $0-2$ & 10 & $(0+2) / 2=1$ & $1 * 10=10$ & $(1-2,07)^{2 * 10=11,40}$ \\
\hline $2-4$ & 2 & $(2+4) / 2=3$ & $3 * 2=6$ & $(3-2,07)^{2 * 2}=1,73$ \\
\hline $4-6$ & 3 & $(4+6) / 2=5$ & $5 * 3=15$ & $(5-2,07)^{2} * 3=25,75$ \\
\hline Total & 15 & - & 31 & 38,88 \\
\hline
\end{tabular}

Source: own creation

$y_{2 \text { middle }}=\frac{\sum_{\mathrm{y} 2 \mathrm{j} * \mathrm{n} 2 \mathrm{j}}}{\mathrm{n} 2 \mathrm{j}}=31 / 15=2,07$ points /educational activities

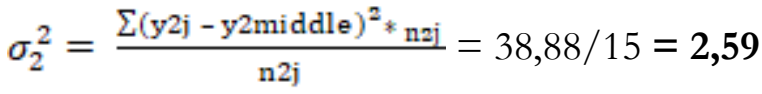

2. $i=3$ (sixth grade)

Tabel 3.4 Educational activities carried out at the sixth grade

\begin{tabular}{|c|c|c|c|c|}
\hline $\begin{array}{c}\text { Growth points of } \\
\text { school results (notes) }\end{array}$ & $\begin{array}{c}\text { Number of } \\
\text { answers } \\
\left(\mathrm{n}_{3 j}\right)\end{array}$ & $\begin{array}{c}\text { Interval } \\
\text { center }\left(\mathrm{y}_{3 j}\right)\end{array}$ & $\mathrm{y}_{3 j}{ }^{*} \mathrm{n}_{3 j}$ & $\left(\mathrm{y}_{3 j}-\mathrm{y}_{3 j \text { middle }}\right)^{2}{ }^{*} \mathrm{n}_{3 j}$ \\
\hline $0-2$ & 8 & $(0+2) / 2=1$ & $1 * 8=8$ & $(1-2,20)^{2} * 8=11,52$ \\
\hline $2-4$ & 5 & $(2+4) / 2=3$ & $3 * 5=15$ & $(3-2,20)^{2} * 5=3,20$ \\
\hline $4-6$ & 2 & $(4+6) / 2=5$ & $5 * 2=10$ & $(5-2,20)^{2} * 2=15,68$ \\
\hline Total & 15 & - & 33 & 30,40 \\
\hline
\end{tabular}

Source: own creation

$y_{3 \text { middle }}=\frac{\sum \mathrm{y} 3 \mathrm{j} * \mathrm{n} 3 \mathrm{j}}{\mathrm{n} 3 \mathrm{j}}=33 / 15=2,20$ points /educational activities

$\sigma_{3}^{2}=\frac{\sum(y 3 j-y 3 \text { middle })^{2} * n s i j}{n 3 j}=30,40 / 15=\mathbf{2 , 0 3}$

3. $i=4$ (seventh grade) 
Tabel 3.5 Educational activities carried out at the seventh grade

\begin{tabular}{|c|c|c|c|c|}
\hline $\begin{array}{c}\text { Growth points of } \\
\text { school results (notes) }\end{array}$ & $\begin{array}{c}\text { Number } \\
\text { of answers } \\
\left(\mathrm{n}_{4 j}\right)\end{array}$ & $\begin{array}{c}\text { Interval } \\
\text { center }\left(\mathrm{y}_{4 j}\right)\end{array}$ & $\mathrm{y}_{4 \mathrm{j}} *_{\mathrm{n}_{4 j}}$ & $\left(\mathrm{y}_{4 \mathrm{j}}-\mathrm{y}_{4 \mathrm{j} \text { middle }}\right)^{2} *_{\mathrm{n}_{4 j}}$ \\
\hline $0-2$ & 12 & $(0+2) / 2=1$ & $1 * 12=12$ & $(1-1,94)^{2 * 12=10,60}$ \\
\hline $2-4$ & 2 & $(2+4) / 2=3$ & $3 * 2=6$ & $(3-1,94)^{2} * 2=2,25$ \\
\hline $4-6$ & 3 & $(4+6) / 2=5$ & $5 * 3=15$ & $(5-1,94)^{2 * 3}=28,09$ \\
\hline Total & 17 & - & 33 & 40,94 \\
\hline
\end{tabular}

Source: own creation

$y_{4 \text { middle }}=\frac{\sum_{\mathrm{y} 4 \mathrm{j} * \mathrm{n} 4 \mathrm{j}}}{\mathrm{n} 4 \mathrm{j}}=33 / 17=1,94$ points /educational activities

$\sigma_{4}^{2}=\frac{\sum(\mathrm{y} 4 \mathrm{j}-\mathrm{y} 4 \mathrm{middle})^{2} \times \mathrm{n} 4 \mathrm{j}}{\mathrm{n} 4 \mathrm{j}}=40,94 / 17=2,41$

4. $i=5$ (eighth grade)

Tabel 3.6 Educational activities carried out at the eighth grade

\begin{tabular}{|c|c|c|c|c|}
\hline $\begin{array}{c}\text { Growth points of } \\
\text { school results (notes) }\end{array}$ & $\begin{array}{c}\text { Number of } \\
\text { answers }\left(\mathrm{n}_{5 j}\right)\end{array}$ & $\begin{array}{c}\text { Interval } \\
\text { center }\left(\mathrm{y}_{5 j}\right)\end{array}$ & $\mathrm{y}_{5 \mathrm{j}} *_{\mathrm{n}_{5 j}}$ & $\left(\mathrm{y}_{5 j}-\mathrm{y}_{5 j \text { middle }}\right)^{2} *_{\mathrm{n}_{5 j}}$ \\
\hline $0-2$ & 2 & $\begin{array}{c}(0+2) / 2= \\
1\end{array}$ & $1 * 2=2$ & $(1-3,56)^{2 * 2}=13,10$ \\
\hline $2-4$ & 9 & $\begin{array}{c}(2+4) / 2= \\
3\end{array}$ & $3 * 9=27$ & $(3-3,56)^{2 * 9}=2,82$ \\
\hline $4-6$ & 7 & $\begin{array}{c}(4+6) / 2= \\
5\end{array}$ & $5 * 7=35$ & $(5-3,56)^{2 * 7}=14,52$ \\
\hline Total & 18 & - & 64 & 30,44 \\
\hline
\end{tabular}

Source: own creation

$y_{5 \text { middle }}=\frac{\sum y 5 j * n 5 j}{n 5 j}=64 / 18=3,56$ points /educational activities

$\sigma_{5}^{2}=\frac{\Sigma(y 5 j-y 5 m i d d l e)^{2} * n s i j}{n 5 j}=30,44 / 18=\mathbf{1 , 6 9}$

I. The average of the group media is calculeted.

$\mathrm{y}_{\text {omiddle }}=\frac{\sum_{\text {yi }} * \mathrm{ni}}{\sum_{\mathrm{ni}}}=(1,75 * 16+2,07 * 15+2,2 * 15+1,94 * 17+3,56 * 18) / 81=189,11 / 81=2,33$

II. The impact of the activities in which children were involved, regardless of class, is calculated.

III.

$\sigma_{\text {imiddle }}^{2}=\frac{\sum \sigma_{i}^{2} * \text { ni }}{\sum \text { nii }}=(1,94 * 16+2,59 * 15+2,03 * 15+2,41 * 17+1,69 * 18) /(16+15+15+17+18)=$ $171,73 / 81=2,12$

$\delta^{2}=\frac{\sum(\text { yi }- \text { ymiddle })^{2} * \text { ni }}{\sum \text { ni }}=\left((1,75-2,33)^{2 * 16}+(2,07-2,33)^{2 * 15}+(2,2-2,33)^{2 * 15}+(1,94-2,33)^{2 *} * 17\right.$ $\left.+(3,56-2,33)^{2 * 18}\right) / 81=36,4678 / 81=\mathbf{0 , 4 5}$

$\sigma^{2}=\sigma_{i \text { middle }}^{2}+\delta_{4}^{2}=2,12+0,45=2,57$

IV. The hypothesis are established:

$\mathrm{H}_{0}: \mu_{1}=\mu_{2}=\mu_{3}=\mu_{4}=\mu_{5}$ (the hypothesis null);

$\mathrm{H}_{1}: \ni \mu_{\mathrm{i}} \neq \mu_{\mathrm{j}}(\mathrm{i} \neq \mathrm{j})$ (the alternative hypothesis). 
Tabel 3.8 Anova - educational activities

\begin{tabular}{|c|c|c|c|c|c|}
\hline $\begin{array}{c}\text { Source of } \\
\text { variation }\end{array}$ & $\begin{array}{c}\text { ss (sum of } \\
\text { squares) }\end{array}$ & $\begin{array}{c}\mathrm{df} \text { (degree } \\
\text { of } \\
\text { freedom) }\end{array}$ & $\begin{array}{c}\text { ms (mean } \\
\text { of squares) }\end{array}$ & $\mathrm{F}_{\text {calc }}$ & $\mathrm{F}_{\text {crit }}$ \\
\cline { 1 - 4 } Between groups & $\mathrm{s}_{1}=36,45$ & $\mathrm{r}-1=4$ & $\mathrm{~S} 1=9,11$ & \multirow{2}{*}{$\mathrm{S} 1 / \mathrm{S} 2=$} \\
4,03 & 2,45 \\
\cline { 1 - 4 } Within groups & $\mathrm{s}_{2}=171,72$ & $\mathrm{n}-\mathrm{r}=76$ & $\mathrm{~S} 2=2,26$ & \\
\cline { 1 - 3 } Total & $\mathrm{s}=208,17$ & $\mathrm{n}-1=80$ & - & \\
\hline
\end{tabular}

Source: own creation

$$
\begin{aligned}
& \mathrm{s}_{1}=\mathrm{n}^{*} \delta^{2}=81 * 0,45=36,45 \\
& \mathrm{~s}_{2}=\mathrm{n} * \sigma^{2}=81 * 2,12=171,72 \\
& \mathrm{~s}=\mathrm{s}_{1}+\mathrm{s}_{2}=36,45+171,72=208,17 \\
& \mathrm{n}=81 \\
& \mathrm{r}-1=5-1=4 \\
& \mathrm{n}-\mathrm{r}=81-5=76 \\
& \mathrm{n}-1=81-1=80 \\
& \mathrm{~S} 1=\mathrm{s}_{1 / \mathrm{r}} \mathrm{r}-1=36,45 / 4=9,11 \\
& \mathrm{~S} 2=\mathrm{s}_{2 /} \mathrm{n}-\mathrm{r}=171,72 / 76=2,26 \rightarrow \mathrm{F}_{\text {calc }}=\mathrm{S} 1 / \mathrm{S} 2=9,11 / 2,26=4,03 \\
& \mathrm{~F}_{\text {crit }}=\mathrm{F}_{\text {tabelat }}=F_{\text {జæ; } r-1 ; n-r} \\
& a-\text { level of significance } \\
& a=5 \%=0,05 \\
& \text { Prob }=(1-a) * 100=(1-0,05) * 100=0,95=95 \% \\
& \mathrm{~F}_{0,05 ; 4 ; 76}=2,45
\end{aligned}
$$

From data analysis results that Fcalc $>$ Fcrit. $\mathrm{H} 0$ is rejected and $\mathrm{H} 1$ is accepted, which means that extracurricular activities have significantly influenced children's results.

Based on the statistical interpretation (the percentage and graphical results) it can conclude that the project has generated positive effects for the members of the community in which it is being implemented.

\section{Conclusions and proposals}

Local development projects with European-funded bring a positive change to the community in which they are implemented contributing to economic well-being. From the analysis of the activities carried out within the local development project implemented in the South-Muntenia region in Giurgiu County, especially the actions in the educational area, resulted that the project contributed significantly to the improvement of the unfavorable situations faced by the locality, such as: school drop-out, low children's educational outcomes, low levels of adult education, and low skills among young people. All the educational activities in which the children were involved have achieved their objectives.

As it resulted from the distributed questionnaire among pupils, they were very pleased with all the activities they had participated in, especially the fact that they took place in the team, the interactive way in which the hours were spent, and the report communication between teachers and children. Also, the Fisher test and statistical interpretation revealed that pupils significantly increased their school results (Table 3.8), as a result of the activities they participated in, and they also improved their relationships with colleagues, learning to collaborate with others.

As a result of the analysis of all the data obtained, the local development project implemented in Greaca commune has significantly contributed to the quality of the educational and health services, as well as to the improvement of the quality of life. Regarding the cost-benefit analysis, relating total revenue costs of the benefits within the project and will be awarded 22 grants. 
If will be finced 22 companies, certainly will increase the revenues from taxes at the local budget, natural capital will be capitalized, the community wil be promoted at regional and national level and will be encouraged the insertion of women into the labor market.

Research has shown that all educational activities have had a positive impact on the community, so is recommended a rigorous programming of the actions, to eliminate all negative elements that can influence the good course of the educational activities, Therefore is proposed a Flow Diagram (Appendix 1) to be used in in the scheduling of every course.

\section{References}

1. Boldeanu, D., Geambasu, C., \& Tudor, C. (2015), Modeling business processes and project management in public administration, Bucharest, Publisher Ase

2. Cohesion Policy 2014-2020, march 2014, consulted at May, 202019 https://ec .europa.eu/regional_policy/sources/docgener/informat/2014/community_en.pdf

3. Constantinescu, D. A., Ungureanu, A. M., \& Pridie (2001), A., Project management, Bucharest, Publisher S.C. Nationala S.A.

4. Dobrescu, A. (2017), Management of projects co-financed by European funds, Bucharest, Publisher Dio

5. Duică, C. M. (2009), Project management, Târgoviste, Publisher Bibliotheca

6. Gareis, R. (2010), Happy Projects!, Bucharest, Publisher Ase

7. Guide to cost-benefit analysis of investment projects, 2008, consulted at May, 20 2019, bttp:/ / old.fonduriue.ro/res/filepicker_users/cd25a597fd-62/Documente_Suport/Studii/ $0_{-}$

Studii_Instrumente_Structurale/Pag.3_ACB/3_Gbid\%20acb_ro_Investitii.pdf

8. Lock, D. (2007), The Essentials of Project Management, England, Publisher Gower

9. Meredith, J. R., \& Mantel Jr., S. J. (2010), Project Management - a managerial approach, Asia, Publisher, John Wiley \& Sons, Inc.

10. Mosteanu, T., \& Iacob, M. (2008), Theories and approaches to the purpose and principles of cost-benefit analysis, Financial and Monetary Policies in the European Union, pp. 7-13

11. Neagu, I. (2008), Monograph of the Greaca commune - Giurgiu County, Turda, Publisher Codrion 